Hobbs, R.W., Huber, B.T., Bogus, K.A., and the Expedition 369 Scientists

Proceedings of the International Ocean Discovery Program Volume 369

publications.iodp.org

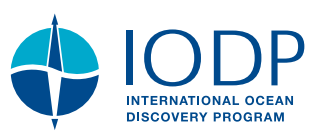

Check for updates

Contents

https://doi.org/10.14379/iodp.proc.369.202.2020

\title{
Data report: petrology and volcanic stratigraphy at Site U1513, IODP Expedition 3691
}

Maria Luisa G. Tejada, ${ }^{2}$ Eun Young Lee, ${ }^{3}$ Seung Soo Chun, ${ }^{3}$ Dennis L. Harry, ${ }^{4}$ Laurent Riquier, ${ }^{5}$ and Carmine C. Wainman ${ }^{6}$

Keywords: International Ocean Discovery Program, IODP, JOIDES Resolution, Expedition 369, Site U1513, Australia Cretaceous Climate and Tectonics, Naturaliste Plateau, petrophysics, Xray diffraction, lava flows

\section{Abstract}

International Ocean Discovery Program (IODP) Expedition 369 recovered the first stratigraphically constrained volcanic sequence at Site U1513 on the eastern flank of the Naturaliste Plateau. We report macroscopic and microscopic core description and petrophysical data from this $82.20 \mathrm{~m}$ thick volcanic sequence (Lithostratigraphic Unit VI). We present a modified volcanic stratigraphy based on postexpedition examination of the core sections from Holes U1513D and U1513E. The volcanic sequence is divided into nine lithologic units consisting of alternating basaltic flows (Units 1, 3, 5, 7, and 9) and volcaniclastic beds (Units 2, 4, 6, and 8$)$, cut by multiple intrusions.

\section{Introduction}

International Ocean Discovery Program (IODP) Site U1513 includes the two deepest holes drilled to date on the Naturaliste Plateau, reaching 756.70 meters below seafloor (mbsf) in Hole U1513D and 770.27 mbsf in Hole U1513E (Huber et al., 2019b). Hole U1513D is located at latitude $33^{\circ} 47.6196^{\prime} \mathrm{S}$, longitude $112^{\circ} 29.1339^{\prime} \mathrm{E}$ (World Geodetic System, 1984), very close to Deep Sea Drilling Project (DSDP) Site 258 (latitude $33^{\circ} 47.69^{\prime}$ S, longitude $112^{\circ} 28.42^{\prime} \mathrm{E}$ ) (Figure F1A) (Davies et al., 1974). Hole U1513E, located at latitude $33^{\circ} 47.6190^{\prime} \mathrm{S}$, longitude $112^{\circ} 29.1204^{\prime} \mathrm{E}$, is $\sim 20.8 \mathrm{~m}$ away from Hole U1513D. The two holes at Site U1513 penetrated through the volcaniclastic-rich sedimentary sequence (Lithostratigraphic Unit V) (Lee et al., 2020) that was only partially recovered at DSDP Site 258 and into the volcanic sequence of Lithostratigraphic Unit VI (Figure
F1B). In this data report, we describe the petrological and petrophysical characteristics of the volcanic sequence and utilize these data to establish a volcanic stratigraphy (Figure F1C) that can be used as a framework for postexpedition studies in the future.

\section{Methods and materials}

The volcanic sequence was recovered at $690.28-756.70 \mathrm{mbsf}$ (interval 369-U1513D-66R-1, $8 \mathrm{~cm}$, to 75R-7, $130 \mathrm{~cm}$ ) in Hole U1513D and 688.07-770.27 mbsf (interval 369-U1513E-2R-4, 0 cm, to $9 \mathrm{R}-5,62 \mathrm{~cm}$ ) in Hole U1513E (Figure F1C). The core sections were broadly described on board the ship and divided into lithologic units based on chilled margins, faulted and fragmented boundaries, and textural and color changes. Bulk density from gamma ray attenuation (GRA) and moisture and density (MAD), $P$-wave velocity, magnetic susceptibility, and natural gamma radiation (NGR) were measured on the core sections and selected discrete samples during the expedition (Huber et al., 2019a; Huber et al., 2019b). Thin sections from selected samples from Hole U1513D were described, and whole-rock X-ray diffraction (XRD) analysis was conducted on the same sample locations on board. However, shipboard preparation of thin sections and mineralogical analyses were not possible for Hole U1513E due to lack of time.

After the expedition, additional thin section analysis was conducted at the Japan Agency for Marine-Earth Science and Technology (JAMSTEC) for Hole U1513E. Archive halves of the core sections from both Holes U1513D and U1513E were reexamined at the Kochi Core Center (KCC), Japan, to better understand the nature and origin of the sedimentary units (previously described as

\footnotetext{
1 Tejada, M.L.G., Lee, E.Y., Chun, S.S., Harry, D.L., Riquier, L., and Wainman, C.C., 2020. Data report: petrology and volcanic stratigraphy at Site U1513, IODP Expedition 369. In Hobbs, R.W., Huber, B.T., Bogus, K.A., and the Expedition 369 Scientists, Australia Cretaceous Climate and Tectonics. Proceedings of the International Ocean Discovery Program, 369 : College Station, TX (International Ocean Discovery Program). https://doi.org/10.14379/iodp.proc.369.202.2020

2 Institute for Marine Geodynamics (IMG), Japan Agency for Marine-Earth Science and Technology, Japan. mtejada@jamstec.go.jp

${ }^{3}$ Faculty of Earth System and Environmental Sciences, Chonnam National University, Republic of Korea.

${ }^{4}$ Department of Geosciences, Colorado State University, USA.

${ }^{5}$ Institut des Sciences de la Terre de Paris (ISTeP), Sorbonne University, France.

${ }^{6}$ Australian School of Petroleum, University of Adelaide, Australia.

MS 369-202: Received 3 October 2019 . Accepted 19 December 2019 . Published 27 March 2020

This work is distributed under the Creative Commons Attribution 4.0 International (CC BY 4.0) license. (c)) BY
} 
Figure F1. A. Map of the Naturaliste Plateau on the southwest Australian margin showing the location of IODP Expedition 369 Site U1513 and DSDP Site 258. Bathymetric contour interval $=500 \mathrm{~m}$; Naturaliste Plateau is defined approximately by the 4000-m contour (modified from Borissova, 2002). B. Lithostratigraphy at Site U1513 (Huber et al., 2019b). C. Volcanic units of Holes U1513D and U1513E. The units are distinguished by changes in dominant lithology, texture, color, and physical properties and by the presence of faults, chilled margins and baked contacts.

A Location of Site U1513
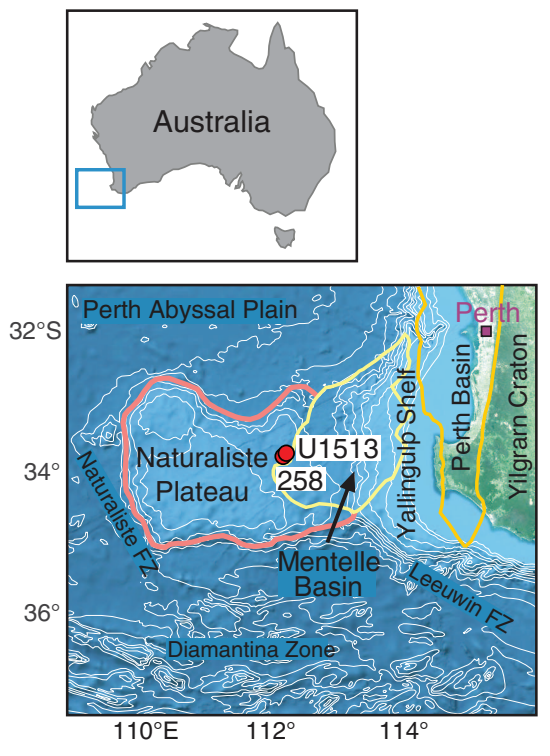

B Lithostratigraphy

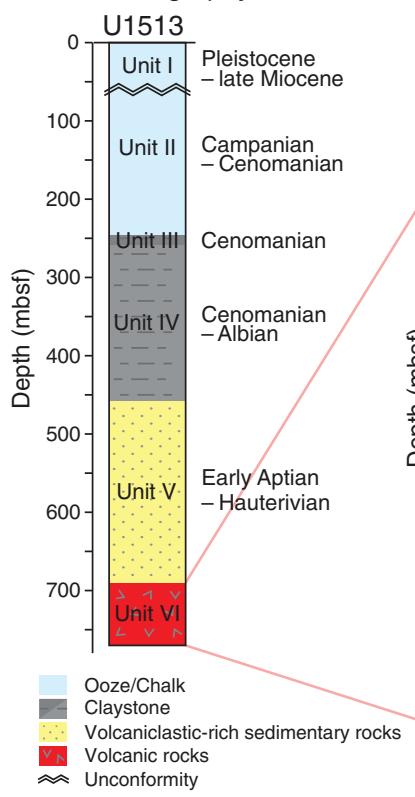

C Volcanic stratigraphy

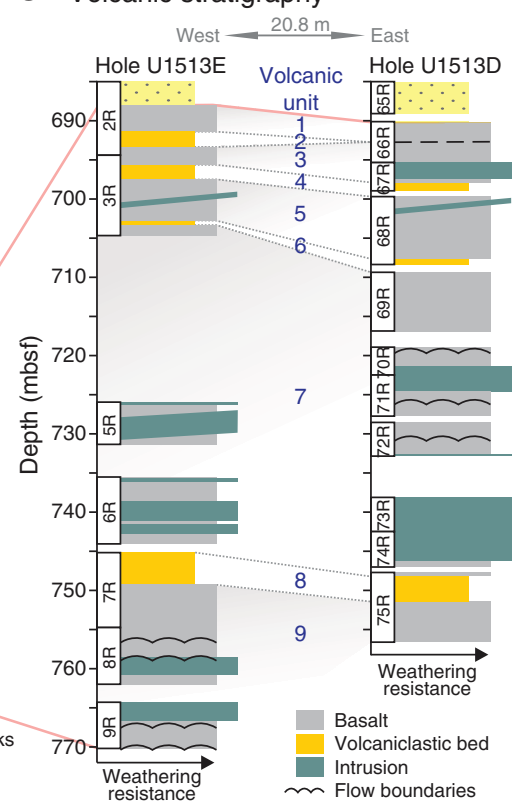

breccia) intercalated with the basalt flows. Lithology, structures, mineralogical composition, grain size, color, bed thickness, and contact type descriptions were extracted from the combined shipboard and postexpedition data sets. Petrophysical data from onboard physical properties measurements (Huber et al., 2019a; Huber et al., 2019b) complemented the macroscopic and microscopic core descriptions and were used to refine lithologic contacts identified during the expedition.

We also conducted additional whole-rock XRD measurements for selected samples from Hole U1513E at the Korea Basic Science Institute (KBSI) Gwangju Center using a D8 Advance X-ray diffractometer with a $\mathrm{Cu}$ source, voltage $=40 \mathrm{kV}$, current $=40 \mathrm{~mA}$, and measurement range of $2 \theta=1^{\circ}-80^{\circ}$. Mineral identification was conducted at the Institut des Sciences de la Terre de Paris (ISTeP), France.

\section{Results}

The volcanic sequence comprises alternating basalt flows and volcaniclastic beds, with a total cored thickness of $82.20 \mathrm{~m}$. It is divided further into 9 lithologic units: Units $1,3,5,7$, and 9 are igneous units, and Units 2, 4, 6, and 8 are volcaniclastic units (Table T1; Figure F1C). Each igneous unit is composed of one to several discrete lava flow units that are $0.05-4.08 \mathrm{~m}$ thick and are variably bounded by chilled margins (common), faults, or textural and color changes (Figure F2). Dolerite dikes and hydrothermal veins intrude the whole volcanic sequence.

The upper boundary of the volcanic sequence is an irregular and disconformable (erosional) contact with a volcaniclastic sandstone that forms the lower part of Lithostratigraphic Unit V (Figure F1B, F1C), which was recovered in Hole U1513E (interval 2R-4, 0-3 cm). In Hole U1513D, a $\sim 1 \mathrm{~m}$ thick interval of poor recovery separates the volcanic sequence from the overlying volcaniclastic-rich sedi-
Table T1. Summary of volcanic stratigraphy, Site U1513. Download table in CSV format.

mentary rocks. The topmost unit has $\sim 20 \mathrm{~cm}$ brecciated flow top that grades downhole into massive basalt flows in Section 66R-1. The total thickness of the drilled volcanic sequence is $66.42 \mathrm{~m}$ in Hole U1513D and $82.20 \mathrm{~m}$ in Hole U1513E, but the lower boundary was not reached.

The excellent correlation between physical properties and lithologic units in Hole U1513D was used as a guide to correlate the lithologic boundaries in Hole U1513E (Figure F3). In both holes, the top of the volcanic sequence is characterized by sharp increases in bulk density and $P$-wave velocity and a drop in NGR values (counts per second; cps). Within the sequence, intervals of low bulk density and $P$-wave velocity, with corresponding spikes in NGR, are associated with the volcaniclastic beds between the basaltic units. Intervals of high bulk density $\left(\sim 2.5 \mathrm{~g} / \mathrm{cm}^{3}\right)$ and $P$-wave velocity $(>3000$ $\mathrm{m} / \mathrm{s}$ ) define intrusions with margins that are either faulted or chilled (e.g., dikes in Unit 7; Figure F3). The increasing degree of alteration of basalts contributes to a decrease in bulk density $\left(<2.0 \mathrm{~g} / \mathrm{cm}^{3}\right)$ and $P$-wave velocity $(\sim 2000 \mathrm{~m} / \mathrm{s})$ and increase in NGR values due to elevated clay mineral content. Magnetic susceptibility in the volcanic sequence is high, ranging from -3 to 3757 IU (instrument units; Huber et al., 2019b), and varies downhole with occasional sharp increases that are attributed to alteration by iron-bearing minerals and paramagnetic clay minerals. The varying degree of alteration also contributes to the petrophysical variation observed within each volcanic unit.

\section{Hole U1513E lithologic units}

Unit 1 is the topmost unit in the volcanic sequence. It is a $3.42 \mathrm{~m}$ thick single massive flow in interval $2 \mathrm{R}-4,0 \mathrm{~cm}$, to $2 \mathrm{R}-6,121 \mathrm{~cm}$, consisting of green-gray porphyritic basalt with olivine, pyroxene, 
Figure F2. Core images of representative volcanic units from Holes U1513D and U1513E. A. Unit 1 basalt flow with large visible plagioclase phenocrysts (369-U1513E-2R-6, 30-60 cm). B. Unit 2 tuff with altered plagioclase and basalt fragments at the base $(369-U 1513 \mathrm{E}-2 \mathrm{R}-8,22-52 \mathrm{~cm})$. C. Unit 3 plagioclase-phyric basalt flow with altered bluish white plagioclase megacrysts (plag); arrow = intrusive finger near the contact with dolerite dike (369U1513D-66R-4, 110-140 cm). D. Unit 4 volcaniclastic flow showing irregular baked upper contact with flow of Unit 3 (369-U1513E-3R-1, 82-112 cm). E. Unit 5 basalt flow showing lobate structure with a curved, chilled margin and thin selvages (369-U1513E-3R-4, 3-33 cm). F. Unit 6 interflow breccia showing red baked contact with upper basalt flow (369-U1513D-68R-6, 86$116 \mathrm{~cm}$ ). G. Unit 7 basalt flow with large phenocrysts of plagioclase (369U1513E-5R-4, 63-93 cm). H. Unit 8 volcaniclastic flow with elongated basaltic clasts and mineral grains (369-U1513E-7R-4, 15-45 cm). I. Unit 9 basalt flow with plagioclase phenocrysts (369-U1513E-9R-5, 30-60 cm). J. Dike with xenolith (369-U1513E-8R-4, 20-50 cm).

Core-section images
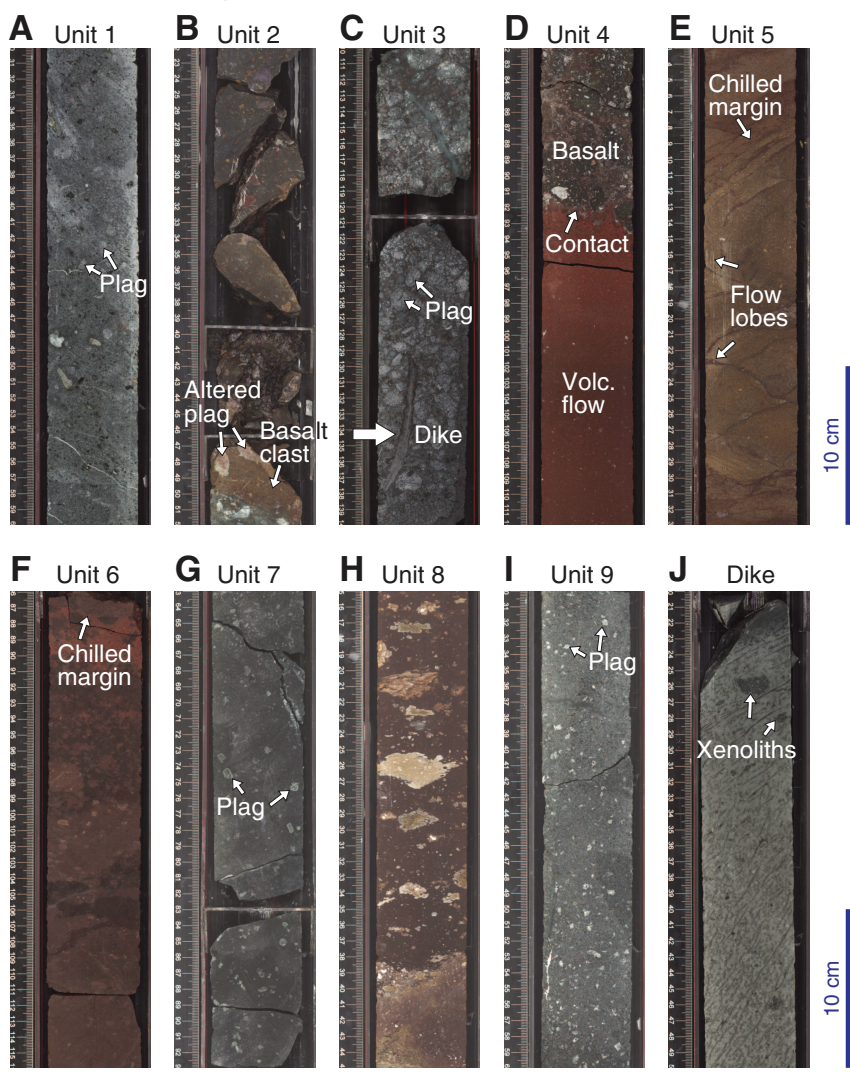

and plagioclase phenocrysts in a fine-grained crystalline groundmass (Table T1; Figures F2A, F4A; see COREPHOTO in Supplementary material). Plagioclase phenocrysts are as long as $3 \mathrm{~cm}$ in the flow interior and appear more altered near the bottom of the flow, where it is cut by several $\leq 1 \mathrm{~cm}$ thick calcite veins. Some intervals of recrystallized groundmass resulting in a pseudoporphyritic texture occur near the veins in all core sections. Olivine phenocrysts are altered and observed only as partial to complete pseudomorphs. A thin section shows a big plagioclase phenocryst and smaller olivine phenocryst with pyroxene rim (Figure F4A). The high bulk density and $P$-wave velocity values for this flow are comparable with those of the intrusive bodies (Figure F3A, F3B) and was considered to be a sill during shipboard core description. The boundary with the underlying volcaniclastic bed is chilled and marked by a brown, sparsely phyric (cryptocrystalline), originally glassy margin with trachytic texture, as indicated by stretched vesicles/amygdules and oriented mineral grains. However, the upper boundary does not show a well-defined chilled margin or baked contact with the overlying sedimentary unit as expected for a sill or dike. Thus, this unit is here interpreted as a single lava flow.

Unit 2 is defined by a $1.95 \mathrm{~m}$ thick interval of dark orange-brown to red-brown tuff in interval $2 \mathrm{R}-6,121 \mathrm{~cm}$, to $2 \mathrm{R}-8,52 \mathrm{~cm}$, between two massive basalt flows, Units 1 and 3 (Figure F2B; see COREPHOTO in Supplementary material). It is poorly sorted and matrix-supported with ochre-yellow granule-sized clasts and angular to subangular pebble-sized fragments of basaltic clasts and mineral grains at the base. It is characterized by higher magnetic susceptibility (as high as $3074 \mathrm{IU}$ ) and moderate NGR values ( $3 \mathrm{cps})$ compared to other volcaniclastic beds (Figure F3C, F3D). It is also structureless, although there is an apparent imbrication of granulesized clasts near the middle (interval 2R-7, 70-90 cm). XRD data indicate that the unit is characterized by abundant goethite, possibly forming the granule-sized clasts, and dominated by rectorite-illite (Figure F5A). Its lower boundary is faulted (fragmented), but there is a preserved brown band with a sharp, irregular basal outline and contains pebble-sized (1-3 cm long), highly angular, altered (argillized and hematized) plagioclase and basaltic fragments of the underlying flow unit (Figure F2B).

Unit 3 is a $2.28 \mathrm{~m}$ thick single massive flow from interval $2 \mathrm{R}-8$, $52 \mathrm{~cm}$, to 3R-1, $92 \mathrm{~cm}$, composed of olivine-plagioclase-phyric basalt (see COREPHOTO in Supplementary material). Plagioclase phenocrysts are as long as $1 \mathrm{~cm}$ (Figures F2C; F4B), whereas olivine grains are small $(0.1-0.3 \mathrm{~mm})$ and altered to brown iddingsite. The groundmass consists of plagioclase laths in ophitic to subophitic relationship with pyroxene. The upper margin shows a thin $2-3 \mathrm{~cm}$ thick flow top breccia with angular to subangular pebble- to granule-sized clasts. It is intersected by several crosscutting calcite veins that are as wide as $1 \mathrm{~cm}$, forming tension gash structures around them. The bottom half of the flow is altered and shows patches of green and maroon-red colors, resembling a mosaic, where isolated basalt fragments are surrounded by red-brown (maroon) alteration material, leading to decreases in bulk density and $P$-wave velocity (Figure F3A, F3B). There is a broad baked contact with the underlying volcaniclastic unit (Unit 4). The boundary where lithology and color change displays irregular or interfingering microstructure (Figure F2D).

Unit 4 is a $1.86 \mathrm{~m}$ thick ash-rich, red to maroon volcaniclastic flow interbed in interval 3R-1, $92 \mathrm{~cm}$, to $3 \mathrm{R}-3,14 \mathrm{~cm}$ (see COREPHOTO in Supplementary material). Its upper boundary is defined by a color change and is marked by a sharp increase in NGR values (to $9.5 \mathrm{cps}$ ). The upper $55 \mathrm{~cm}$ is bright red and fine grained, showing a well-defined irregular baked contact with overlying Unit 3. The unit is massive, with four clast-rich intervals. Clasts consist of altered basalts and mineral fragments (Figure F4C). XRD analysis shows that the fine-grained matrix contains goethite and is dominated by kaolinite group minerals (probably dickite) and hematite (Figure F5B). This unit displays a gradational boundary with the underlying highly altered brown basalt flows of Unit 5 , showing a cobble-sized basalt clast broken up into smaller fragments at the bottom.

Unit 5 is a $5.25 \mathrm{~m}$ thick compound flow in interval $3 \mathrm{R}-3,14 \mathrm{~cm}$, to $3 \mathrm{R}-7,104 \mathrm{~cm}$ (see COREPHOTO in Supplementary material). The upper half consists of thin, elongated flow lobes 7-12 cm wide with curved chilled margins (Figure F2E) and grades into a massive flow in the lower half. These flows are brown to greenish brown, highly to completely altered, and have flow banding structure. Some 
Figure F3. Correlation plots of physical properties with volcanic units of Holes U1513E and U1513D. Bulk density is based on gamma ray attenuation (GRA) and moisture and density (MAD). cps = counts per second., IU = instrument units.

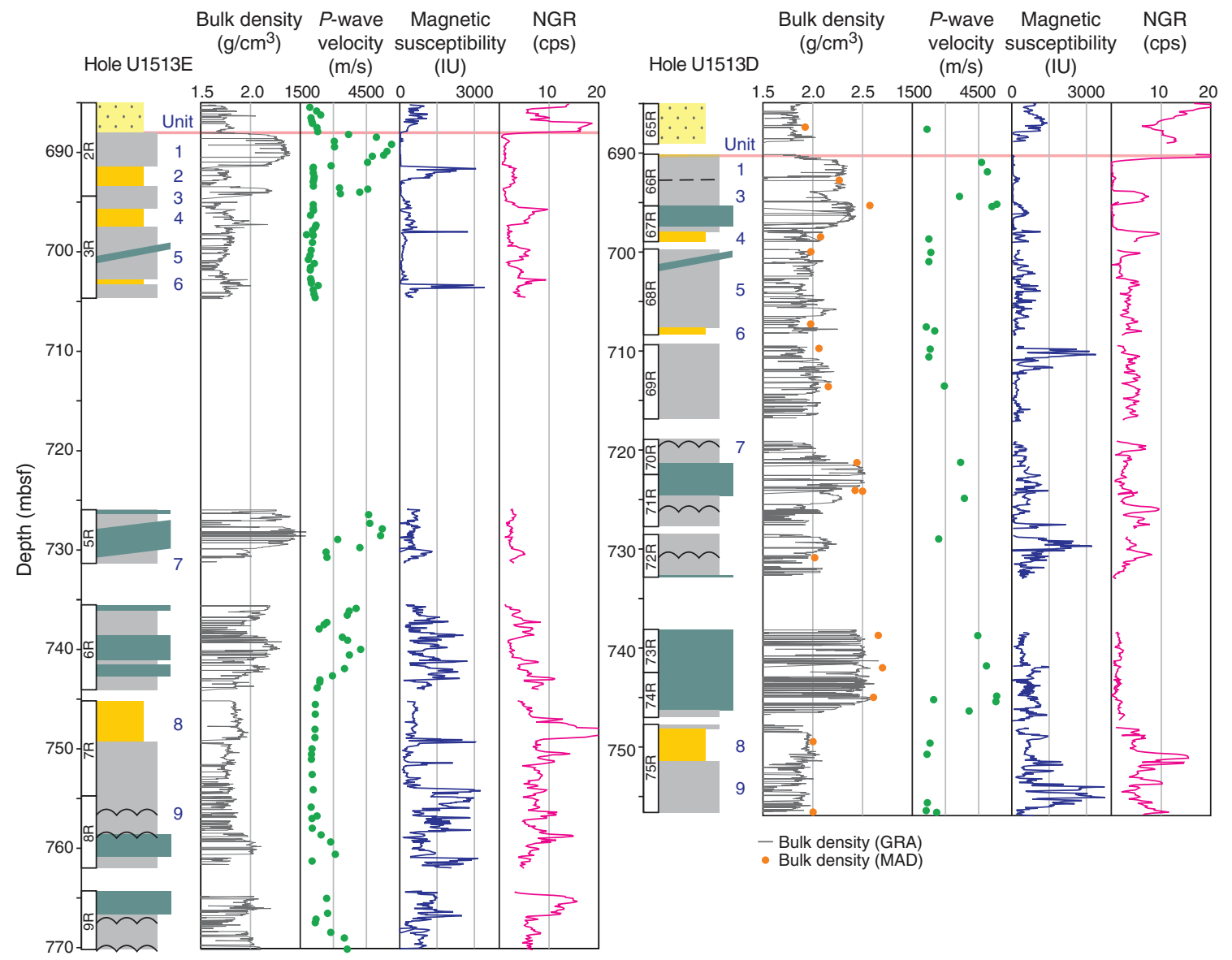

portions show pillow-like structure with radial cracks and chilled selvages. Altered hyaloclastites and volcaniclastic matrix are observed between curved flow boundaries. The bottom of this lithologic unit is a broad, red baked contact with the underlying volcaniclastic bed (Unit 6). A steeply dipping green-gray dike crosscuts this unit. Two intrusion lobes with greenish gray core and dark to light brown chilled margins are also observed in the same Section 3R-6 (see COREPHOTO in Supplementary material). The dike has an equigranular texture and is relatively fresher than the flows it intrudes.

Unit 6 is a $59 \mathrm{~cm}$ thick lithic-rich red to maroon volcaniclastic interflow bed in interval 3R-7, $104 \mathrm{~cm}$, to 3R-8, $18 \mathrm{~cm}$ (see COREPHOTO in Supplementary material). Some clasts are bigger than cobble in size, grading downhole to flat, highly angular and imbricated smaller clasts. It is matrix-supported with mostly reddish brown (maroon) sandy matrix at the bottom. The upper contact with Unit 5 is a baked, red band with chilled margin, and its lower boundary rests on the trachytic and vesicular flow top of the underlying highly altered brown massive basalt flow of Unit 7 .

Unit 7 includes the bottom of interval 3R-8, 18-149 cm, to Section 6R-7, with an estimated total thickness of $40.65 \mathrm{~m}$. The upper boundary is marked by a sharp increase in magnetic susceptibility (Figure F3C). The $1.31 \mathrm{~m}$ thick portion of Unit 7 in Section 3R-8 consists of sparsely vesicular fine-grained aphyric basalt with a brown, highly altered flow top exhibiting trachytic texture. The vesicles are highly elongated and stretched parallel to flow margins.
Most of the vesicles are filled with clay minerals and zeolite. The bottom $20 \mathrm{~cm}$ of the section shows relatively fresher version of this flow unit, with highly angular vesicles. There is a $21.27 \mathrm{~m}$ core recovery gap (Core 4R) between the bottom of this core and the rest of Unit 7 flows that was recovered in Hole U1513D. The basalt flows in Cores 369-U1513E-5R and 6R are considered part of this same lithologic unit (Unit 7) based on the continuous drilling results in Hole U1513D. The less altered cores recovered downhole are dark gray to black massive flows of amygdaloidal basalts composed of altered olivine-( \pm pyroxene) and plagioclase phenocrysts in intersertal to spherulitic groundmass (Figure F2G). These flows display vuggy to amygdaloidal textures in moderately to highly altered portion at the basal flow margins (Sections 369-U1513E-6R-5 to 6R-7; see COREPHOTO in Supplementary material). Vugs and cavities are round to elongate and are lined with calcite, sometimes with native copper and malachite. The vugs become highly irregular in shape toward the bottom of the flow. Unit 7 flows are cut by fine-grained aphyric dolerite dikes that contain xenoliths of porphyritic basalt showing diffuse margins. Dikes cut the flows along faults with steep $\left(>70^{\circ}\right)$ dips or display steeply dipping chilled margins. Native copper occurs as vein fillings and as disseminations along the vein margins within the dolerite dikes. Relatively high bulk density (2.2-2.5 $\left.\mathrm{g} / \mathrm{cm}^{3}\right)$ and $P$-wave velocity $(3200-5200 \mathrm{~m} / \mathrm{s})$ intervals correspond to dolerite dikes of Unit 7 (Figure F3A, F3B).

Unit 8 is a $3.6 \mathrm{~m}$ thick dark reddish gray volcaniclastic flow deposit in interval 7R-1, $0 \mathrm{~cm}$, to 7R-4, $78 \mathrm{~cm}$ (Figure F2H). This unit 
Figure F4. Representative thin section images from Holes U1513D and U1513E, showing petrographic details for selected lithologic units. A. Unit 1 plagioclase megacryst and olivine phenocryst with pyroxene rim (Sample 369-U1513E-2R-4, 0-2 cm, in plane polarized light [PPL] and crossed polarized light $[X P L])$. B. Unit 3 with large plagioclase phenocrysts showing clay alteration along cracks (Sample 369-U1513D-66R-4, 43-46 cm, XPL and PPL). C. Unit 4 showing poorly sorted basalt clasts and mineral grains (Sample 369-U1513D-67R-4, 62-65 cm, PPL). D. Unit 8 showing mineral grains and basaltic clasts in volcaniclastic beds (Sample 369-U1513D-75R-3, 52-54 cm, $P P L)$. E. Fine-grained dolerite dike with intergranular texture between plagioclase and clinopyroxene (Sample 369-U1513D-74R-2, 20-22 cm, XPL). OI $=$ olivine, Plag $=$ plagioclase, $\mathrm{Cpx}=$ clinopyroxene.

\section{Thin-section images}
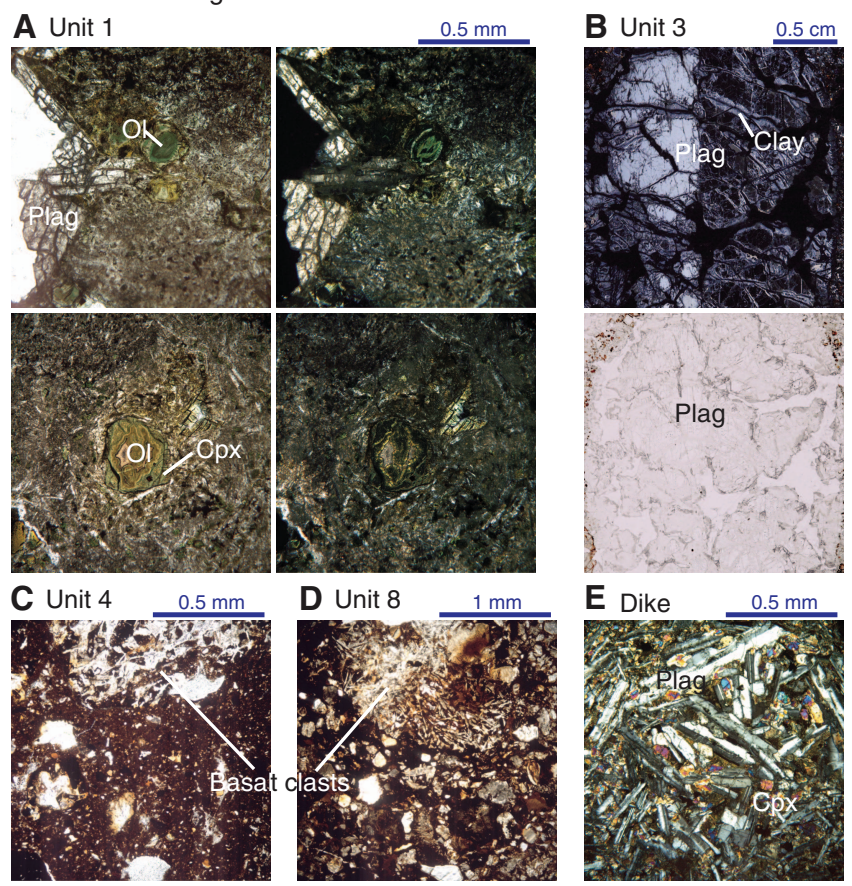

is poorly sorted and matrix-supported with clasts grading in size from cobble to granule. Larger clasts display grain orientation layering, and interclast matrix diminishes toward the base. Clasts consist of altered basalts and mineral fragments (Figure F4D), and XRD analysis reveals goethite, abundant kaolinite group minerals (probably dickite), and hematite in the matrix (Figure F5C). The upper boundary with the overlying flows is not recovered, but its contact with the underlying compound flows of Unit 9 appears gradational. It has similar clasts and matrix to Unit 4.

Unit 9 consists of interval 7R-4, $37 \mathrm{~cm}$, to $9 \mathrm{R}-5,62 \mathrm{~cm}$ (end of hole), with a recovered thickness of $21.7 \mathrm{~m}$ (see COREPHOTO in Supplementary material; Figure F1C). It consists of highly altered brown aphyric to trachytic plagioclase-phyric flows in the upper part that change downhole to fresher green-gray massive porphyritic flows of olivine-plagioclase-phyric basalt (Figure F2I). Several intervals of basalt agglomerates and faulted horizons were encountered, separating several flow units. The top $0.5 \mathrm{~m}$ of the topmost flow unit consists of several thin (6-15 cm-thick) lobes of sparsely vesicular porphyritic basalt that are superimposed on top of one another and separated by chilled boundaries or brecciated material. They grade into a $3.1 \mathrm{~m}$ thick massive flow of similar lithology. These flows have trachytic texture, defined by subparallel alignment of feldspar laths that are altered to clay and by highly elongated vesicles. They also display flow banding with chilled outlines. This
Figure F5. XRD mineralogical identification for Hole U1513E Unit 2 (Sample $2 \mathrm{R}-8,20-22 \mathrm{~cm})$, Unit $4(3 \mathrm{R}-2,30-32 \mathrm{~cm})$, and Unit $8(7 \mathrm{R}-3,110-112 \mathrm{~cm})$.

XRD mineralogical determination for volcaniclastic beds
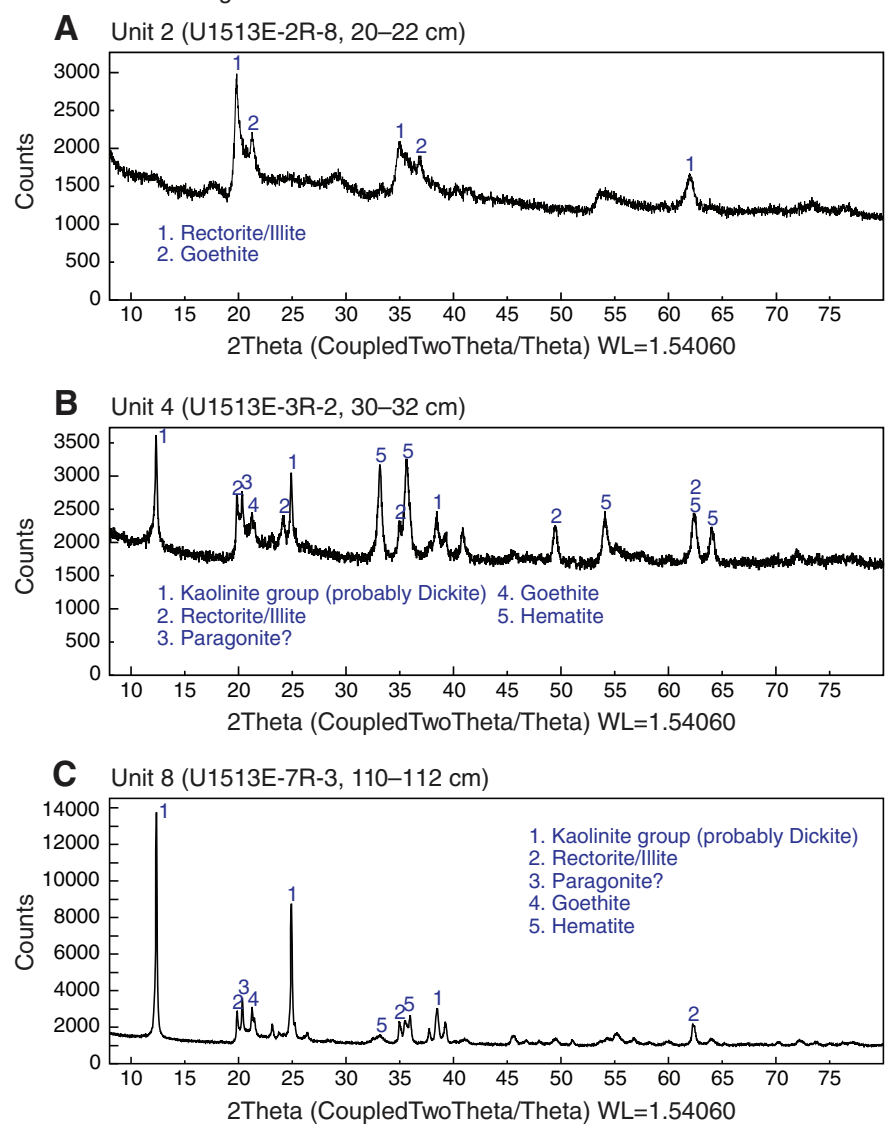

compound flow is underlain by a package of intercalated highly altered, reddish brown to reddish black massive flows of aphyric basalt flows and agglomerates that range in thickness from 0.7 to 2.8 $\mathrm{m}$. The original glassy matrix is completely replaced by hematite and some parts show agglutinated clasts of basalt with chilled margins producing patchy, fragmental texture. The texture changes downhole to green and brown mosaic with interconnected brown interstitial material due to alteration by hematite. Variable alteration of $\mathrm{Fe}$-Ti oxides to hematite (maghemite) or magnetite to goethite (in Hole U1513D) may be related to highly varying magnetic susceptibility in Unit 9 (Figure F3C). The bottom of this flow package is a highly altered, red-brown aphyric basalt with fragmental flow top and chilled lower margin. It is cut by a broad, brown vertical vein, apparently connected to a dike that displays crisscrossing structure resulting from incipient brown alteration along microfractures (Figure F2J). Near the intrusion, the host flow is highly altered, with native copper dissemination, and is cut by a network of hematite veins and hematite-calcite veins that form tension gash structure between them. The lowermost flow unit has a moderately vesicular to amygdaloidal plagioclase-phyric glassy flow top. The amounts of vesicles and amygdules decrease from the flow margin and change to a massive flow interior composed of moderately altered porphyritic basalt with plagioclase and olivine (pseudomorphs) phenocrysts in a fine-grained intergranular groundmass composed of plagioclase laths and interstitial pyroxene and $\mathrm{Fe}-\mathrm{Ti}$ oxides. 
Three relatively high bulk density $\left(1.9-2.2 \mathrm{~g} / \mathrm{cm}^{3}\right)$ and high $P$ wave velocity $(2700-3600 \mathrm{~m} / \mathrm{s})$ intervals are observed within the lower part of Unit 9, around $760 \mathrm{mbsf}, 765 \mathrm{mbsf}$ and $769 \mathrm{mbsf}$ (Figure F3A, F3B) and correspond to relatively less altered rocks. The upper two high-density intervals are also characterized by moderate to high NGR values (5-15 cps) (Figure F3D). Detailed scrutiny reveals that these two high-density zones consist of relatively fresher feldspar-rich rocks that contain xenoliths and steeply inclined $\left(\sim 70^{\circ}\right)$ chilled margins or fracture surfaces and are therefore interpreted as dikes (Figure F1C). These dikes are moderately altered greenish gray holocrystalline feldspar-rich dikes with aligned black to red (magnetite or hematite) grains. Incipient brown alteration results in lineated structure. The feldspathic nature of these dikes may explain the associated high NGR values. The dike margins are either faulted or chilled. The coarser-grained interior of the dikes consists dominantly of plagioclase laths that show intergranular to intersertal texture with greenish (altered to chlorite) interstitial pyroxene and oxide grains (Figure F4D). Black to dark gray xenoliths of porphyritic basalt are also observed (e.g., Figure F2J).

\section{Hole U1513D lithologic units}

Unit 1 in Hole U1513D is a 2.58 m thick moderately to weakly altered massive flow of dark gray basalts recovered in interval 369U1513D-66R-1, $8 \mathrm{~cm}$, to 66R-2, $128 \mathrm{~cm}$ (Table T1; see COREPHOTO in Supplementary material). Its boundary with overlying Lithostratigraphic Unit V is not recovered, but the upper part of the recovered portion of this unit is brecciated (flow top breccia) with no trace of baking. The basalt flow is aphyric to porphyritic with $60 \%$ plagioclase phenocrysts that are $1-3 \mathrm{~cm}$ long. The groundmass increases in grain size from fine to coarse grained and is completely to partially replaced by hematite from the margins toward the interior of the flow. This unit is less altered in Hole U1513E, where olivine phenocrysts are also visible, together with large $(1-3 \mathrm{~cm}$ long) plagioclase phenocrysts in microcrystalline groundmass. The boundary with underlying Unit 3 flow is fragmented and finegrained aphyric, with planar fracture surfaces infilled with hematite and calcite veins.

The volcaniclastic bed (Unit 2) is not present at Hole U1513D (Figure F1C; see COREPHOTO in Supplementary material). This may be explained by faulting, as indicated by the fractured and fragmented boundary between Units 1 and 3 .

Unit 3, recovered in interval 369-U1513D-66R-3, $0 \mathrm{~cm}$, to 67R$4,28 \mathrm{~cm}$, is thicker ( $5.19 \mathrm{~m}$ thick) and more altered than the correlative unit in Hole U1513E (2.28 m thick), with pseudoporphyritic groundmass texture and large megacrysts of plagioclase that are partially altered to bluish white clay (Figures F2C, F4B). The groundmass is largely replaced by hematite, with patches of remaining fresher groundmass creating pseudoporphyritic texture. The partially altered large plagioclase phenocrysts in moderately hematized groundmass made the cores appear strangely speckled with bluish white spots right after recovery on deck. The bottom of the flow displays trachytic texture with sparse angular but highly stretched vesicles (as long as $1 \mathrm{~cm}$ ) and aligned plagioclase laths near the red-orange-colored baked contact with underlying volcaniclastic flow (Unit 4). Above the baked contact, the flow displays chilled to trachytic texture away from the lithologic boundary. It is intruded by a dolerite dike with equigranular texture and xenoliths of porphyritic basalt with diffuse outlines (Figure F2C). The dike corresponds to a comparatively high bulk density interval $(\sim 2.4$ $\mathrm{g} / \mathrm{cm}^{3}$ ) (Figure F3A). Alteration of plagioclase crystals to K-rich sericite and clay minerals may explain the high NGR values (as high as $7.5 \mathrm{cps}$ ) reflected in the middle part of this unit toward the contact with the dike (Figure F3D).

Unit 4 in Hole U1513D was not recovered fully and is only $\sim 0.96$ $\mathrm{m}$ thick. It has a $\sim 10 \mathrm{~cm}$ thick bright red horizon at the baked contact with overlying Unit 3, which is very similar to that observed in Hole U1513E (see COREPHOTO in Supplementary material). The unit grades in color downward to dark maroon-brown. It is a massive, poorly sorted, volcanic ash-rich bed with four clast-rich intervals and defined by high NGR values as high as $\sim 9.6 \mathrm{cps}$. Clasts consist of altered basalts and mineral grains (Figure F3C) and the fine-grained matrix is dominated by dickite and hematite. The underlying boundary with Unit 5 was not recovered.

Unit 5 is a $7.95 \mathrm{~m}$ thick compound flow recovered in Core 68R, consisting of several highly to completely altered ochre-brown, thin (5-20 cm thick) aphyric amygdaloidal basalt flow lobes with curved quenched margins in the upper part (see COREPHOTO in Supplementary material). The unit changes downhole into a greenish gray, less altered succession of several lobate or pillowed flows to 55 $\mathrm{cm}$ thick with curved brown, originally glassy margins. Glassy margins preserve trachytic texture formed by microcrystalline plagioclase laths. The bottom flow of the unit is a $\sim 2 \mathrm{~m}$ thick, relatively massive flow of fine-grained aphyric basalt that has a chilled bottom margin with up to $10 \%$ very angular to highly elongate vesicles and amygdules. This basal unit displays a sharp red-orange baked contact with the underlying volcaniclastic bed of Unit 6. The upper boundary with the overlying volcaniclastic flow (Unit 4) is not recovered but appears gradational in Hole U1513E. This compound flow unit is intruded by $\sim 25 \mathrm{~cm}$-wide inclined dike that is also present in Hole U1513E (Figure F1C).

Unit 6 is a relatively thin volcaniclastic interbed between two basalt flow sequences recovered in interval $68 \mathrm{R}-6,80-149 \mathrm{~cm}$. It is a $69 \mathrm{~cm}$ thick, highly altered interflow breccia that changes in texture downhole from cobble to pebble-sized clast-supported to granulesized matrix-supported framework. Bigger clasts are angular to subangular and composed mostly of basalts, and the pebble to granule-sized clasts are more subangular to subrounded with uncertain composition due to alteration.

Unit 7 consists of $39.1 \mathrm{~m}$ thick section of massive amygdaloidal basalt flows in interval 69R-1, $0 \mathrm{~cm}$, to $75 \mathrm{R}-1,70 \mathrm{~cm}$ (see COREPHOTO in Supplementary material). The uppermost $90 \mathrm{~cm}$ of the unit is a reddish brown highly altered and oxidized flow top of amygdaloidal basalt displaying highly angular amygdules that are stretched toward the top margins. This interval is overprinted with brown to red-brown alteration wherein hematite fills the vesicles and replaces the original plagioclase and pyroxene phenocrysts. The presence of Fe-rich minerals corresponds to high magnetic susceptibility values (as high as $3228 \mathrm{IU}$ ) measured in this interval and at $\sim 730$ mbsf (Figure F3C). The lowermost $80 \mathrm{~cm}$ of the unit is fragmented and not well recovered $(\sim 70 \mathrm{~cm}$ recovery gap), but evidence of baking and chilled margins is observed near the contact with the underlying volcaniclastic bed (Unit 8). At least four flow units can be delineated; flow boundaries are indicated by highly vesicular fragmented intervals and/or with original glassy matrix completely replaced by hematite. The composition of the moderate to least altered portions of the unit is \pm olivine-pyroxene-plagioclase-phyric basalts with subophitic to spherulitic-textured groundmass of plagioclase, pyroxene, and Fe-Ti oxides. Cores of plagioclase phenocrysts are mostly altered to green-black minerals. The bottom margin of the lowermost flow is highly altered, with both phenocrysts and groundmass completely replaced by hematite, which also fills the highly elongated vesicles toward the bottom. The unit is 
intruded by dolerite dikes in several places near flow contacts and close to the bottom boundary with the underlying volcaniclastic bed (Unit 8 ). The dikes are characterized by high bulk density (2.4$2.7 \mathrm{~g} / \mathrm{cm}^{3}$ ) and high $P$-wave velocity (as high as $5261 \mathrm{~m} / \mathrm{s}$ ) intervals and corresponding low NGR values of $0-3$ cps (Figure F3). They are fine- to medium-grained holocrystalline aphyric dolerite with xenoliths of porphyritic basalt. The dikes have relatively fresher interiors but are altered near the contacts with the volcaniclastic unit (Unit $8)$. The contacts with the flows are fractured, mostly showing steeply dipping $\left(>70^{\circ}\right)$ chilled margins. They are composed of large ( $>2 \mathrm{~mm}$ sized) phenocrysts of olivine (altered), pyroxene (twinned), and plagioclase (as long as $1 \mathrm{~cm}$ ) in spherulitic to intergranular textured groundmass of plagioclase, pyroxene, and iron oxides (Figure F4E). Xenoliths of porphyritic basalt are commonly observed.

The interflow volcaniclastic bed designated as Unit 8 is very similar in character with that in Hole U1513E but is only $3.0 \mathrm{~m}$ thick in Hole U1513D (interval 75R-1, $70 \mathrm{~cm}$, to 75R-4, $20 \mathrm{~cm}$; see COREPHOTO in Supplementary material). Evidence of slight baking and chilled margin is observed in broken fragments near the boundary with overlying basalt flows of Unit 7. Its boundary with the lowermost lithologic unit (Unit 9) appears gradational. It is generally massive but the lower $\sim 70 \mathrm{~cm}$ shows clast- to matrix-supported flattened fragments of the underlying basalt flow in subhorizontal orientation, and the middle part consists of cobble-sized or larger elongated clasts. The framework changes from matrix-supported pebble- to granule- sized fragments to massive, very coarse-grained sandstone toward the top (Figure $\mathbf{F} 2 \mathbf{H}$ ). The volcaniclastic bed is maroon to reddish brown with both clasts and matrix replaced by hematite. XRD data also reveal the presence of kaolinite mineral group (probably dickite), other clay minerals (rectorite-illite), and $\mathrm{K}-\mathrm{Fe}-\mathrm{Mg}$ micas (sericite) in the matrix.

Only the uppermost $5.2 \mathrm{~m}$ of Unit 9 was recovered in Hole U1513D. The recovered upper portion is composed of highly altered brown lobate flows that become a massive flow downhole. The flow top is trachytic with highly angular and elongated vesicles as long as $5 \mathrm{~mm}$. The middle part is also highly altered and brown, with fragmental texture resembling agglomeration of basaltic fragments. The lowermost $20 \mathrm{~cm}$ is composed of greenish gray highly vesicular (up to $70 \%$ vesicles) aphyric basalt flow with highly irregular and angular vesicles. Hematite and brown clay alteration of the flows, together with magnetite/goethite, as shown by onboard XRD analysis of Sample 75R-7, 65-67 cm, contribute to the high magnetic susceptibility (as high as 3757 IU) and elevated NGR values (as high as $11.5 \mathrm{cps}$ ) (Figure F3C, F3D). The moderately altered greenish fragments at the bottom of the hole indicate this flow is composed of aphyric basalt very similar to the recovered upper flows at Hole U1513E.

\section{Acknowledgments}

The authors thank the captain and crew of R/V JOIDES Resolution and the technical staff of the International Ocean Discovery Program (IODP) for the successful implementation of Expedition 369. We acknowledge financial support by the Japan Drilling Earth Science Consortium (J-DESC) to M.L.G.T., by K-IODP funded by the Ministry of Oceans and Fisheries and the Korea Research Fellowship program by the Ministry of Science and Information and Communication Technology (ICT) through the National Research Foundation of Korea (2017H1D3A1A01054745) to E.Y.L. and
S.S.C., by US Science Support Program Post-Expedition Research Award (70GG00939) to D.L.H, by the European Consortium for Ocean Research Drilling (ECORD) and IODP-France to L.R., and by the Australia-New Zealand IODP Consortium (ANZIC) to C.C.W. ANZIC is supported by the Australian Government through the Australian Research Council's LIEF funding scheme (LE160100067) and the Australian and New Zealand consortium of universities and government agencies. Special thanks go to Erik Wolfgring, Tao Jiang, Michael Wagreich, Bernhard Schnetger, and Hans-Jürgen Brumsack for core sample analyses and to Yusuke Kubo, Shigako Nigi, Toshikuni Yabuki, and Ryo Yamaoka of the Kochi Core Center for facilitating our visit and core descriptions (Request No. 071241IODP). Comments and suggestions by H.K.H. Olierook and B.T. Huber improved this manuscript.

\section{References}

Borissova, I., 2002. Geological Framework of the Naturaliste Plateau. Geoscience Australia, 2002/20. http://www.ga.gov.au/metadata-gateway/metadata/record $/ 40535 /$

Davies, T.A., Luyendyk, B.P., Rodolfo, K.S., Kempe, D.R.C., McKelvey, B.C., Leidy, R.D. et al., 1974. Site 258. In Davies, T.A., Luyendyk, B.P., et al., 1974. Initial Reports of the Deep Sea Drilling Project, 26: Washington, DC (U.S. Government Printing Office). https://doi.org/10.2973/dsdp.proc.26.111.1974

Huber, B.T., Hobbs, R.W., Bogus, K.A., Batenburg, S.J., Brumsack, H.-J., do Monte Guerra, R., Edgar, K.M., Edvardsen, T., Garcia Tejada, M.L., Harry, D.L., Hasegawa, T., Haynes, S.J., Jiang, T., Jones, M.M., Kuroda, J., Lee, E.Y., Li, Y.-X., MacLeod, K.G., Maritati, A., Martinez, M., O'Connor, L.K., Petrizzo, M.R., Quan, T.M., Richter, C., Riquier, L., Tagliaro, G.T., Wainman, C.C., Watkins, D.K., White, L.T., Wolfgring, E., and Xu, Z., 2019. Expedition 369 methods. In Hobbs, R.W., Huber, B.T., Bogus, K.A., and the Expedition 369 Scientists, Australia Cretaceous Climate and Tecton$i c s$. Proceedings of the International Ocean Discovery Program, 369: College Station, TX (International Ocean Discovery Program). https://doi.org/10.14379/iodp.proc.369.102.2019

Huber, B.T., Hobbs, R.W., Bogus, K.A., Batenburg, S.J., Brumsack, H.-J., do Monte Guerra, R., Edgar, K.M., Edvardsen, T., Garcia Tejada, M.L., Harry, D.L., Hasegawa, T., Haynes, S.J., Jiang, T., Jones, M.M., Kuroda, J., Lee, E.Y., Li, Y.-X., MacLeod, K.G., Maritati, A., Martinez, M., O'Connor, L.K., Petrizzo, M.R., Quan, T.M., Richter, C., Riquier, L., Tagliaro, G.T., Wainman, C.C., Watkins, D.K., White, L.T., Wolfgring, E., and Xu, Z., 2019. Site U1513. In Hobbs, R.W., Huber, B.T., Bogus, K.A., and the Expedition 369 Scientists, Australia Cretaceous Climate and Tectonics. Proceedings of the International Ocean Discovery Program, 369: College Station, TX (International Ocean Discovery Program). https://doi.org/10.14379/iodp.proc.369.104.2019

Lee, E.Y., Wolfgring, E., Tejada, M.L.G., Harry, D.L., Wainman, C.C., Chun, S.S., Schnetger, B., et al., 2020. Early Cretaceous subsidence of the Naturaliste Plateau defined by a new record of volcaniclastic-rich sequence at IODP Site U1513. Gondwana Research, 82:1-11. https://doi.org/10.1016/j.gr.2019.12.007

Tejada, M.L.G., Lee, E.Y., Chun, S.S., Harry, D.L., Riquier, L., and Wainman, C.C., 2020. Supplementary material, https://doi.org/10.14379/iodp.proc.369.202supp.2020. Supplement to Tejada, M.L.G., Lee, E.Y., Chun, S.S., Harry, D.L., Riquier, L., and Wainman, C.C., 2020. Data report: petrology and volcanic stratigraphy at Site U1513, IODP Expedition 369. In Hobbs, R.W., Huber, B.T., Bogus, K.A., and the Expedition 369 Scientists, Australia Cretaceous Climate and Tectonics. Proceedings of the International Ocean Discovery Program, 369: College Station, TX (International Ocean Discovery Program). https://doi.org/10.14379/iodp.proc.369.202.2020 